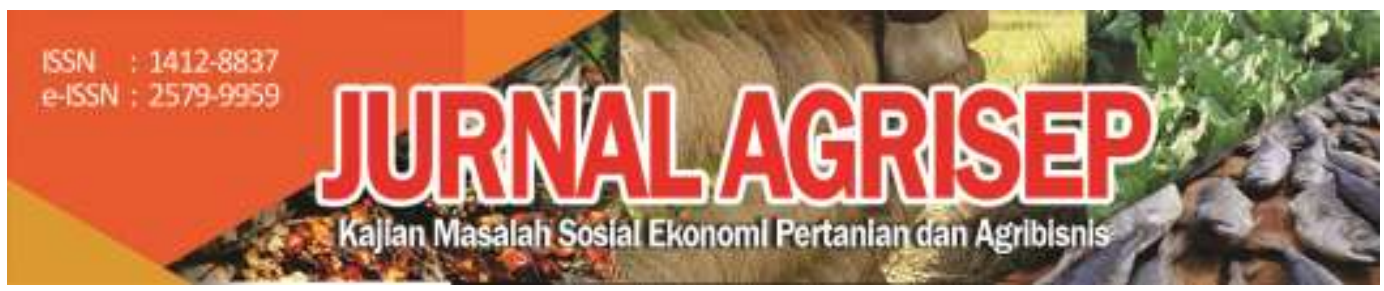

DOI: $10.31186 /$ jagrisep.19.1.109-126

\title{
FAKTOR PENENTU PENDAPATAN WANITA BURUH TANI PADI SAWAH DAN KONTRIBUSINYA TERHADAP PENDAPATAN KELUARGA (Studi Kasus : Di Desa Wonosari Kecamatan Megang Sakti Kabupaten Musi Rawas)
}

\author{
Income Determination Factors Female Farm Laborer Rice Fields And Its \\ Contributions To Family Income (Case Study: On Wonosari Village, \\ Megang Sakti Sub-District, Musi Rawas District)

\section{Ella Anggraini1) $\square$; Basuki Sigit Priyono²) ; Sriyoto ${ }^{3)}$} \\ 1),2),3) Jurusan Sosial Ekonomi Pertanian Fakultas pertanian Universitas \\ Bengkulu \\ Email: ellaanggraini@gmail.com
}

\begin{abstract}
This study aims to : 1) analyze work out time female farm laborer rice fields on Wonosari Village Megang Sakti Sub-District; Musi Rawas District; 2) Calculate income female farm laborer rice fields on Wonosari Village Megang Sakti Sub-District, Musi Rawas District; 3) Analyze income determinantion factors female farm laborer rice fields on Wonosari Wonosari Village Megang Sakti Sub-District, Musi Rawas District; 4) Calculate the contribution of the income female farm laborer on Wonosari Village Megang Sakti Sub-District, Musi Rawas District. The quantitative method used to analyse survey data. The result shown from this study are: 1) the average amount work time women farm laborer on farming rice fields on Wonosari Village the amount is 445 hours/Cultivating season; 2) the income women farm laborer rice fields on Wonosari Village is Rp3.071.194.-/CS; 3) There are three variables that have significant effect out of the five independent variables to income women farm labourer rice fields on Wonosari village that is age, total family dependents and farming experience; 4) The average contribution of women farm laborer to family income on Wonosari Village is 15,7 percent.
\end{abstract}

Keywords: Female farm Laborer, Outpouring, Income, Contribution 


\section{ABSTRAK}

Tujuan penelitian ini adalah: 1) Menganalisis curahan waktu kerja wanita buruh tani padi sawah di Desa Wonosari Kecamatan Megang Sakti Kabupaten Musi Rawas; 2) Menghitung pendapatan wanita buruh tani padi sawah di Desa Wonosari Kecamatan Megang Sakti Kabupaten Musi Rawas; 3) Menganalisis faktor penentu pendapatan wanita buruh tani padi sawah di Desa Wonosari Kecamatan Megang Sakti Kabupaten Musi Rawas; 4) Menghitung kontribusi pendapatan wanita buruh tani padi sawah terhadap pendapatan keluarga di Desa Wonosari Kecamatan Megang Sakti Kabupaten Musi Rawas. Metode penelitian kuantitatif digunakan untuk menganalisis data. Hasil yang ditunjukkan dari penelitian ini adalah 1) Rata-rata curahan waktu kerja wanita buruh tani pada usahatani padi sawah di Desa Wonosari yang dicurahkan adalah sebesar $445 \mathrm{Jam} / \mathrm{MT}$; 2) Pendapatan wanita buruh tani padi sawah di Desa Wonosari adalah sebesar Rp3.071.194.-/MT; 3) Terdapat tiga variabel dari lima variabel bebas yang berpengaruh terhadap pendapatan wanita buruh tani padi sawah di Desa Wonosari Kecamatan Megang Sakti yaitu umur, jumlah tanggungan keluarga dan lama pengalaman bertani. 4) Rata-rata kontribusi pendapatan wanita buruh tani pada usahatani padi sawah terhadap pendapatan keluarga di Desa Wonosari Kecamatan Megang Sakti sebesar 15,7 persen.

Kata Kunci: Wanita Buruh tani, Curahan, Pendapatan, Kontribusi

\section{PENDAHULUAN}

Indonesia merupakan negara agraris, oleh karenanya pemerintah masih menitikberatkan pembangunan pada sektor pertanian khususnya di pedesaan. Pembangunan sektor pertanian di pedesaan, diharapkan mampu meningkatkan pendapatan dan taraf hidup rumah tangga petani. (Yuwono, 2013). Dengan demikian petani dan wanita tani memiliki peran penting sebagai salah satu tonggak penghasil pangan. Mereka terlibat dalam semua tahap kegiatan usahatani, mulai dari pengolahan tanah, sampai dengan pemasaran hasil, khususnya pada kegiatan pencabutan bibit, penanaman, penyiangan, pemanenan, dan pasca panen.

Kegiatan usahatani yang dilakukan wanita tani dipengaruhi oleh curahan waktu kerja (Sabainingrum,1998). Curahan waktu kerja adalah proporsi waktu bekerja (yang dicurahkan untuk kegiatan-kegiatan tertentu di sektor pertanian dan di luar sektor pertanian). Ada jenis-jenis kegiatan yang memerlukan curahan waktu yang banyak dan kontinyu, tapi sebaliknya ada pula jenis-jenis kegiatan yang memerlukan curahan waktu kerja yang terbatas (Nurmanaf, 2006). Peran wanita dalam keluarga selain sebagai ibu rumah tangga, wanita juga dapat bekerja. Waktu yang dicurahkan seorang wanita dalam kegiatan bekerja mencari nafkah mendapatkan imbalan berupa pendapatan, sehingga wanita tani dapat memberikan kontribusi terhadap pendapatan keluarga. 
Pendapatan wanita tani adalah sesuatu imbalan jasa yang didapatkan oleh wanita tani dari hasil jerih payah yang dilakukan oleh wanita tani saat mereka bekerja pada kegiatan usahatani padi sawah sebagai buruh tani (upahan) di lahan milik orang lain. Pendapatan tersebut berkontribusi besar terhadap pendapatan keluarga. Berkaitan dengan tersebut terdapat beberapa faktor. Faktor-faktor yang diduga sebagai faktor penentu pendapatan wanita tani diantaranya yaitu faktor umur, tingkat pendidikan, pendapatan suami/anggota keluarga lainnya, jumlah tanggungan keluarga dan pengalaman usahatani.

Tinggi rendahnya pendapatan wanita buruh tani akan berpengaruh pada besar kecilnya kontribusi pendapatan wanita buruh tani terhadap pendapatan keluarga (Sumantri dan Budi, 2004). Kontribusi merupakan bentuk keikutsertaan diri wanita buruh tani dalam bekerja pada usahatani padi sawah untuk dapat menambah penghasilan keluarga dalam memenuhi kehidupan sehari-hari. Keikutsertaan wanita buruh tani yang bekerja pada usahatani padi sawah masih banyak dilakukan oleh masyarakat di Desa Wonosari.

Wonosari merupakan desa yang terletak di Kecamatan Megang Sakti Kabupaten Musi Rawas, Sumatera Selatan. Desa Wonosari merupakan salah satu desa yang masih banyak melakukan usahatani padi sawah, kondisi ini didukung oleh daerah yang cocok digunakan untuk usahatani padi sawah. Tidak hanya petani pria yang terlibat dalam kegiatan usahatani padi sawah, tetapi wanita tani di desa tersebut masih banyak yang ikut membantu dalam kegiatan usahatani padi sawah. Kegiatan usahatani padi sawah telah dilakukan turun temurun oleh masyarakat sekitar yang mayoritas bekerja sebagai petani.

Penelitian ini bertujuan untuk menganalisis curahan waktu kerja wanita buruh tani padi sawah, menghitung pendapatan wanita buruh tani padi sawah, menganalisis faktor penentu pendapatan wanita buruh tani padi sawah, dan menghitung kontribusi pendapatan wanita buruh tani padi sawah terhadap pendapatan keluarga petani di Desa Wonosari Kecamatan Megang Sakti Kabupaten Musi Rawas.

\section{METODE PENELITIAN}

\section{Metode Penentuan Lokasi Penelitian}

Penentuan lokasi penelitian ini dilakukan secara sengaja (purposive) di Desa Wonosari Kecamatan Megang Sakti Kabupaten Musi Rawas. Penelitian dilaksanakan pada tanggal 1-28 Februari 2019. Penelitian ini sengaja dipilih sesuai dengan pertimbangan bahwa di Desa Wonosari berdasarkan data Badan Pusat Statistik (2018) terdapat 674 rumah tangga tani yang memiliki usahatani padi sawah, sehingga membuka peluang kerja wanita dalam kegiatan usahatani.

Metode Penentuan Responden 
Populasi dalam penelitian ini adalah wanita buruh tani yang ada di Desa Wonosari Kecamatan Megang Sakti yang berjumlah 80 jiwa. Untuk menentukan besarnya jumlah sampel dalam data kuantitatif digunakan rumus Slovin dengan tingkat kesalahan sebesar 5\%, maka didapat jumlah sampel sebanyak 67 responden.

\section{Metode Pengumpulan Data}

Data yang digunakan dalam penelitian adalah data primer dan data skunder.

\section{Metode Analisis Data}

\section{Analisis Curahan Waktu Kerja Wanita Tani}

Analisis data yang digunakan untuk menghitung curahan waktu tani adalah analisis deskriptif. Rumus yang digunakan adalah (Yunilas, 2005):

$$
C W K=C W K 1+C W K 2+C W K 3+C W K 4
$$

Keterangan: CWK: Total curahan waktu kerja wanita buruh tani pada usahatani padi sawah (Jam/MT); CWK1: Jumlah curahan waktu pencabutan bibit (Jam/MT); CWK2: Jumlah curahan waktu penanaman (Jam/MT); CWK3: Jumlah curahan waktu penyiangan (Jam/MT); CWK4: Jumlah curahan waktu pemanenan (Jam/MT)

\section{Analisis Pendapatan Wanita Buruh Tani}

Untuk melihat pendapatan wanita buruh tani pada usahatani padi sawah, secara matematis dirumuskan sebagai berikut:

$$
P d i=C W K \times U K W
$$

Dimana Pdi: Pendapatan wanita buruh tani padi sawah (Rp/MT); CWK: Total curahan waktu kerja wanita buruh tani padi sawah (Jam/MT); UKW: Upah kerja wanita buruh tani padi sawah (Rp/Jam)

\section{Analisis Faktor Penentu Pendapatan Wanita Buruh Tani}

Faktor-faktor yang mempunyai pengaruh terhadap pendapatan wanita buruh tani, Dianalisis dengan analisis regresi berganda dengan formulasi sebagai berikut (Djarwanto, 2001):

$$
\mathrm{Y}=\mathrm{f}\left(\mathrm{X} \_1, \mathrm{X} \_2, \mathrm{X} \_3, \mathrm{X} \_4, \mathrm{X} \_5\right) \text {. }
$$

Maka,

$$
\mathrm{Y}=\mathrm{a}+\beta 1 \mathrm{X} 1+\beta 2 \mathrm{X} 2+\beta 3 \mathrm{X} 3+\beta 4 \mathrm{X} 4+\beta 5 \mathrm{X} 5+\mathrm{e} .
$$

112 | Ella Anggraini; Basuki Sigit Priyono; Sriyoto; Faktor Penentu Penda... 
Keterangan: Y: Pendapatan Wanita Buruh Tani (Rp/MT); a: Konstanta; $\beta 1$ - $\beta 5$ : Koefisien Regresi; X1 : Umur (Th); X2: Tingkat Pendidikan (Th); X3: Penghasilan Suami/Anggota Keluarga Lainnya (Rp/MT); X4 : Jumlah tanggungan keluarga(Jiwa); X5: Pengalaman Bertani (Th); e: Standar error

\section{Uji Asumsi Klasik}

\section{Uji Normalitas}

Pengujian normalitas dapat dilakukan dengan uji kolmogorov-smirnov, dengan acuan syarat data berdistribusi normal jika nilai probabilitas atau $\mathrm{p}>$ 0,05 (Setyadharma, 2010).

\section{Uji Heteroskedastisitas}

Heterokedastisitas diuji dengan menggunakan grafik scatterplot. Jika titik-titik yang ada membentuk suatu pola tertentu yang teratur (bergelombang), maka terjadi heterokedastisitas. Jika tidak ada pola yang jelas, titik-titik menyebar di atas dan di bawah angka nol pada sumbu Y, maka tidak terjadi heterokedastisitas (Setyadharma, 2010).

\section{Uji Multikolinearitas}

Untuk mendeteksi suatu model regresi bebas multikolinearitas dapat dilakukan dengan pengamatan terhadap beberapa hal berikut (Setyadharma, 2010): Mempunyai nilai Variance Inflation Factor (VIF) di sekitar angka 1 dan mempunyai nilai tolerance mendekati angka 1 . Koefisien korelasi antar variabel independen haruslah lemah (di bawah 0,5).

\section{Uji Statistik}

\section{Koefisien Determinasi (R2)}

Uji ini dilakukan untuk menguji ketepatan model serta mengetahui besarnya proporsi pengaruh variabel bebas terhadap variabel terikat .

\section{Uji Simultan (Uji F)}

Uji F ini dilakukan untuk melihat pengaruh variabel-variabel independen terhadap variabel dependen secara keseluruhan. Kriteria pengambilan keputusan:

1. Jika Fhitung > Ftabel atau - Fhitung < - Ftabel, maka terima Hi dan tolak H0, artinya semua faktor atau variabel bebas secara keseluruhan berpengaruh nyata terhadap pendapatan wanita buruh tani padi sawah.

2. Jika Fhitung $\leq$ Ftabel atau - Fhitung $\geq$ - Ftabel, maka tolak Hi dan terima H0, artinya semua faktor atau variabel bebas secara keseluruhan berpengaruh tidak nyata terhadap pendapatan wanita buruh tani padi sawah. 


\section{Uji Parsial (Uji t)}

Uji ini dilakukan untuk melihat pengaruh variabel bebas secara individu terhadap variabel terikat, dengan menganggap variabel bebas lainnya konstan. kriteria pengujiannya adalah sebagai berikut:

1. Jika thitung > ttabel atau - thitung < - ttabel, maka terima Hi dan tolak H0, artinya salah satu variabel bebas mempengaruhi variabel terikat secara signifikan.

2. Jika thitung $\leq$ ttabel atau - thitung $\geq$ - ttabel, maka tolak Hi dan terima H0, artinya salah satu variabel bebas tidak mempengaruhi variabel terikat secara signifikan

\section{Analisis Besar Kontribusi Pendapatan Wanita Tani Terhadap Pendapatan Keluarga}

Untuk menghitung kontribusi pendapatan wanita tani padi sawah terhadap pendapatan keluarga, secara matematis dirumuskan sebagai berikut (Prasetyo, 2016):

$$
\text { Kontribusi pendapatan }=\frac{\text { Pendapatan } \text { Wanita Usahatani } P \text { Padi } \operatorname{Sawah}(R p / M T)}{\text { Total Pendapatan } \text { Keluarga }(R p / M T)} \times 100 \%
$$

Menurut Sumantri dan Budi (2004), untuk menetapan besar kecilnya kontribusi tenaga kerja wanita terhadap total pendapatan keluarga, maka kriteria pengukuran sebagai berikut: a) Sangat rendah $\quad(1 \%-20 \%)$; Rendah (21\%-40\%); c) Sedang/cukup : $(41 \%-60 \%)$; d) Tinggi $(61 \%-80 \%)$; dan e) Sangat tinggi ( $\geq 80 \%)$.

\section{HASIL DAN PEMBAHASAN}

\section{Karakteristik Wanita Buruh Tani Padi Sawah}

Karakteristik Wanita Buruh Tani di Desa Wonosari Kecamatan Megang Sakti dapat diperinci berdasarkan umur, pendidikan, pekerjaan, lama pengalaman bertani, jumlah tanggungan keluarga dan pendapatan suami/anggota keluarga lainnya. Untuk lebih jelasnya disajikan pada Tabel 1.

Berdasarkan hasil penelitian, umur rata-rata wanita buruh tani padi sawah di Desa Wonosari adalah 45 tahun artinya usia ini termasuk dalam usia produktif dalam bekerja. Dimana pada usia produktif wanita buruh tani mempunyai kemampuan berfikir dan lebih cepat dalam menyelesaikan kegiatan buruh taninya, sedangkan wanita buruh tani yang berumur tua atau tidak produktif mempunyai pengalaman usaha tani yang lumayan lama namun tidak dengan kemampuannya dalam menyelesikan kegiatan buruh tani. Kondisi ini disebabkan produktivitasnya menjadi berkurang. 
Tabel 1. Karakteristik Wanita Buruh Tani di Desa Wonosari

\begin{tabular}{|c|c|c|c|c|}
\hline No & Uraian & Frekuensi & $\begin{array}{l}\text { Persentase } \\
\quad(\%)\end{array}$ & Rata-rata \\
\hline \multirow[t]{4}{*}{1} & Umur & & & \\
\hline & $-\quad 28-40$ & 22 & 33 & \\
\hline & $-\quad 41-53$ & 31 & 46 & 45 tahun \\
\hline & - $\quad 54-66$ & 15 & 21 & \\
\hline \multirow[t]{5}{*}{2} & Tingkat Pendidikan (tahun) & & & \\
\hline & - $\quad$ Tidak Sekolah & 3 & 4,5 & \\
\hline & - $\quad$ SD/ Sederajat & 55 & 82,1 & 6 tahun \\
\hline & - $\quad$ SMP/ Sederajat & 8 & 11,9 & \\
\hline & - $\quad$ SMA/ Sederajat & 1 & 1,5 & \\
\hline \multirow[t]{4}{*}{3} & Pekerjaan Sampingan & & & \\
\hline & $\begin{array}{l}\text { - Tidak memiliki pekerjaan } \\
\text { sampingan }\end{array}$ & 65 & 97 & \\
\hline & - $\quad$ Pedagang & 1 & 1 & 0 \\
\hline & - Warung & 1 & 1 & \\
\hline \multirow[t]{4}{*}{4} & Lama Pengalaman Bertani (tahun) & & & \\
\hline & $\begin{array}{l}-\quad 4-17 \\
-\end{array}$ & 27 & 40 & \\
\hline & $-\quad 18-31$ & 30 & 45 & 20 tahun \\
\hline & $-\quad 32-45$ & 10 & 15 & \\
\hline \multirow[t]{4}{*}{5} & Jumlah tanggungan Keluarga (jiwa) & & & \\
\hline & $-1-3$ & 55 & 82 & \\
\hline & $-\quad 4-6$ & 12 & 18 & 3 jiwa \\
\hline & $\begin{array}{l}-\quad 7-9 \\
\end{array}$ & 0 & 0 & \\
\hline \multirow[t]{5}{*}{6} & Pendapatan $\quad$ Suami/Anggota & & & \\
\hline & Keluarga Lainnya (Rupiah/MT) & & & \\
\hline & $\begin{array}{l}-\quad 2.000 .000-5.700 .000\end{array}$ & 28 & 42 & \\
\hline & - $\quad 5.800 .000-9.500 .000$ & 25 & 37 & $\mathrm{Rp}$ 6.343.284/MT \\
\hline & $9.600 .000-13.300 .000$ & 14 & 21 & \\
\hline
\end{tabular}

Sumber: Data primer diolah, 2019

Berdasarkan hasil penelitian tingkat pendidikan rata-rata wanita buruh tani padi sawah di Desa Wonosari adalah 6 tahun, artinya pada umumnya wanita buruh tani adalah tamatan SD. Pendidikan wanita buruh tani tergolong rendah, hal ini bukan menjadi suatu hambatan untuk bekerja sebagai buruh tani karena untuk bekerja sebagai buruh tidak memerlukan tingkat pendidikan yang tinggi namun lebih kepada pengalaman bertani.

Berdasarkan Tabel 1. Rata-rata wanita buruh tani tidak memiliki pekerjaan sampingan, mereka lebih fokus menjadi wanita tani. Berdasarkan data yang didapat dari lapangan hanya 2 wanita buruh tani yang memiliki pekerjaan sampingan yaitu pedagang dan warung, sedangkan 65 wanita buruh 
tani lainnya tidak memiliki pekerjaan sampingan. Kendala wanita buruh tani tidak mencari pekerjaan sampingan karena skill yang mereka miliki kurang.

Berdasarkan hasil penelitian lama pengalaman bertani bagi wanita buruh tani padi sawah yaitu rata-rata 20 tahun, dimana range 4-44 tahun. Lama pengalaman bertani ini menunjukkan bahwa wanita buruh tani di Desa Wonosari tersebut mempunyai pengalaman yang cukup lama dalam bekerja menjadi wanita buruh tani padi sawah.

Berdasarkan penelitian jumlah tanggungan keluarga tergolong sedang yaitu rata-rata sebanyak 3 jiwa, dimana range 1-6 jiwa. Hal ini juga akan berpengaruh pada pendapatan wanita buruh tani. Semakin banyak jumlah keluarga wanita tani, maka wanita tani akan lebih termotivasi untuk memperhatikan pekerjaan. Mengingat hasil yang optimal akan menjadi pengaruh untuk pendapatan keluarganya.

Dari Tabel 1. Rata-rata pendapatan suami/anggota keluarga lainnya sebesar Rp 6.343.284,-/MT. Jika pendapatan suami/anggota keluarga lainnya tinggi kemungkinan kecil wanita tani akan ikut bekerja dalam membantu mencari tambahan pendapatan, sedangkan jika pendapatan suami/anggota keluarga lainnya rendah kemungkinan besar wanita tani akan ikut bekerja dalam membantu mencari tambahan pendapatan.

\section{Curahan Waktu Kerja Wanita Buruh Tani}

Waktu kerja wanita buruh tani dalam penelitian ini dicurahkan pada 4 tahap kegiatan usahatani padi sawah yaitu pencabutan bibit $\left(\mathrm{CWK}_{1}\right)$, penanaman $\left(\mathrm{CWK}_{2}\right)$, penyiangan $\left(\mathrm{CWK}_{3}\right)$, dan pemanenan $\left(\mathrm{CWK}_{4}\right)$. Curahan waktu kerja dalam satu kali musim tanam yaitu selama 4 bulan (120 hari) oleh sebab itu satuan yang digunakan adalah jam per musim tanam (Jam/MT). Jika waktu kerja yang digunakan rata-rata per hari adalah 6 jam maka total waktu kerja selama 4 bulan adalah $740 \mathrm{Jam} / \mathrm{MT}$. Rata-rata curahan waktu kerja wanita buruh tani disajikan pada Tabel 2 .

\section{Tabel 2. Rata - Rata Curahan Waktu Kerja Wanita Buruh Tani (Jam/MT)}

\begin{tabular}{llcc}
\hline No & Uraian & $\begin{array}{c}\text { Jumlah Curahan Waktu Kerja } \\
\text { (jam/MT) }\end{array}$ & $\%$ \\
\hline 1 & Pencabutan bibit & 27,4 & 6,16 \\
& (CWK1) & 164,1 & 36,88 \\
2 & Penanaman (CWK2) & 1,4 & 0,31 \\
3 & Penyiangan (CWK3) & 252,0 & 56,64 \\
4 & Pemanenan (CWK4) & 444,9 & 100 \\
\hline & Total & & \\
\hline
\end{tabular}

Sumber : Data Primer diolah, 2019

Hasil penelitian menunjukkan curahan waktu kerja wanita buruh tani rata-rata untuk kegiatan buruh tani padi sawah adalah 445 Jam/MT, dimana buruh tani wanita mencurahkan paling banyak waktu pada saat pemanenan. Hal ini dkarenakan pada saat pemanenan, kegiatan harus dilakukan dengan

116 | Ella Anggraini; Basuki Sigit Priyono; Sriyoto; Faktor Penentu Penda... 
segera untuk mendapatkan hasil produksi yang maksimal, sehingga petani mengerahkan lebih banyak tenaga kerja dalam proses ini. Waktu yang tidak digunakan untuk buruh tani padi sawah adalah $270 \mathrm{Jam} / \mathrm{MT}$. Sisa waktu wanita buruh tani biasa mereka gunakan untuk kegiatan lain (pekerjaan domestik). Kondisi ini disebabkan petani yang melakukan usahatani padi sawah memang tidak menggunakan tenaga kerja buruh tani setiap hari. Menurut Shinta (2011), tenaga kerja yang harus dicurahkan oleh laki-laki, wanita dan anak-anak dalam satu tahun yaitu: 1) Tenaga kerja laki-laki sebesar 300 HOK/Tahun; 2) Tenaga kerja wanita sebesar 200 HOK/Tahun; 3) Tenaga kerja anak-anak sebesar 140 HOK/Tahun.

Jika dalam satu tahun waktu kerja yang harus dicurahkan sebesar 200 HOK, maka dalam satu kali musim tanam padi sawah waktu yang harus dicurahkan wanita buruh tani sebesar 66,7 HOK (66,7 Jam/MT). Sehingga dapat dikatakan bahwa curahan waktu kerja wanita buruh tani di Desa Wonosari tergolong tinggi yaitu sebesar $445 \mathrm{Jam} / \mathrm{MT}$. Penelitian ini diperkuat oleh hasil penelitian Yusmaniar $d k k$ dan Muttaqin $d k k$ (2015) yang menunjukkan bahwa curahan waktu kerja wanita dalam rumah tangga lebih banyak digunakan untuk kegiatan produktif (mencari nafkah) dibandingkan kegiatan reproduktif (pekerjaan domestik).

\section{Rata-rata Pendapatan Wanita Buruh Tani Padi Sawah}

Pendapatan ini diperoleh dari upah kerja pada usahatani padi sawah milik orang lain pada tahap kegiatan pencabutan bibit, penanaman, penyiangan dan pemanenan dalam satu kali musim tanam. Sistem pembayaran upah yang sudah menjadi tradisi di masyarakat Desa Wonosari sangat berpengaruh dalam kehidupan mereka. Sistem pembayaran upah untuk setiap tahap kegiatan usahatani berbeda-beda baik menggunakan uang tunai atau gabah. Pembayaran menggunakan uang tunai pada kegiatan penanaman dan penyiangan, sedangkan pada kegiatan pencabutan bibit dan pemanenan menggunakan gabah atau sering disebut bawon.

Besar upah pada tahap kegiatan pencabutan bibit yaitu $5 \mathrm{~kg}$ gabah atau senilai Rp 20.000,- selama 4 jam/hari. Kegiatan pencabutan bibit biasanya dimulai dari pukul 08.00 WIB. Pada tahap penanaman besar upah uang tunai senilai Rp 40.000,- selama 6 Jam/hari. Kegiatan penanaman biasanya dimulai dari pukul 07.00 WIB. Untuk tahap penyiangan besar upah uang tunai senilai Rp 50.000,- selama 6 Jam/hari. Selanjutnya untuk kegiatan penyiangan dimulai dari pukul 08.00 WIB. Ketika pemanenan besar upah bawon yang diterima sebesar 12,5 Kg gabah atau senilai Rp 50.000,- selama 7 Jam/hari. Kegiatan pemanenan biasanya dimulai dari pukul 08.00 WIB. Rata-rata pendapatan wanita buruh tani pada penelitian ini dapat dilihat pada Tabel 3. 
Tabel 3. Rata-Rata Pendapatan Wanita Buruh Tani Pada Setiap Tahap Kegiatan Usahatani Padi Sawah di Desa Wonosari

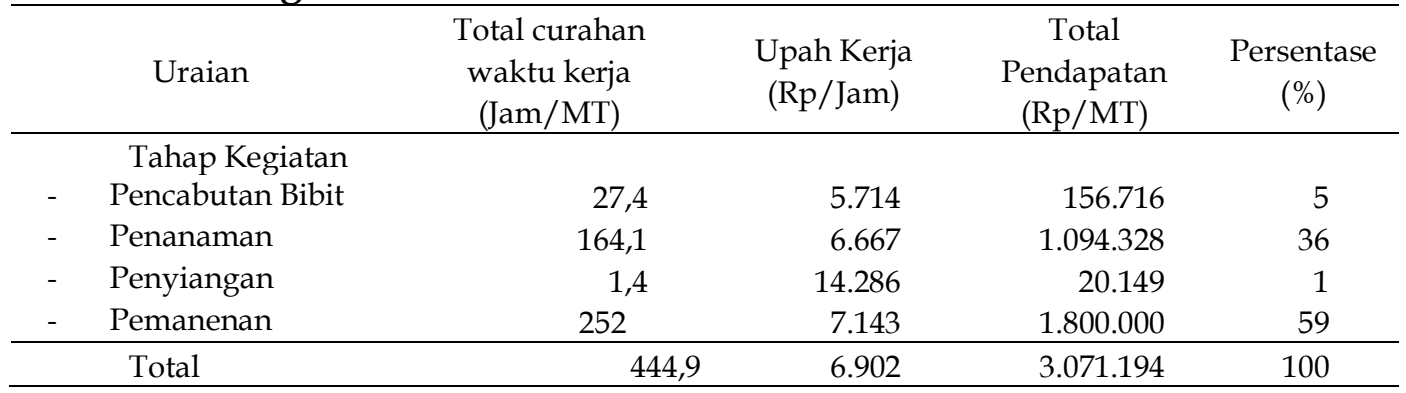

Sumber: Data primer diolah, 2019

Berdasarkan Tabel 3 diketahui bahwa total rata-rata pendapatan wanita buruh tani padi sawah di Desa Wonosari sebesar Rp 3.071.194,-/MT. Pendapatan yang diperoleh wanita buruh tani termasuk dalam kriteria yang rendah. Namun pendapatan wanita buruh tani ini dianggap sangat membantu perekonomian keluarga khususnya untuk memenuhi kebutuhan hidup seharihari.

\section{Faktor Penentu Pendapatan Wanita Buruh Tani}

Untuk mengetahui faktor penentu terhadap pendapatan wanita buruh tani digunakan metode analisis regresi linier berganda.

\section{Uji Asumsi Klasik}

Uji asumsi klasik digunakan untuk memperoleh hasil regresi tidak bias atau agar model regresi BLUE (Best Linier Unbiased Estimator).

\section{Uji normalitas}

Berdasarkan hasil pengujian grafik normal probability plot yang disajikan pada Gambar 1, dapat dilihat bahwa titik-titik menyebar disekitar garis diagonal, serta penyebarannya mengikuti arah garis diagonal.

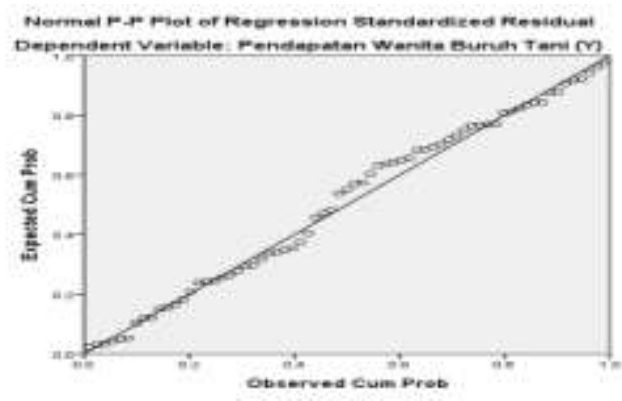

Gambar 1. Hasil Uji Normalitas

118 | Ella Anggraini; Basuki Sigit Priyono; Sriyoto; Faktor Penentu Penda... 
Pengujian distribusi data yang dilakukan dengan metode grafis ini menunjukkan hasil yang dapat disimpulakan bahwa model regresi layak digunakan karena telah memenuhi asumsi normalitas.

\section{Uji Heterokedastisitas}

Berdasarkan hasil uji regresi bahwa penyebaran data tidak membentuk pola yang jelas, titik-titik data menyebar di atas dan di bawah angka 0 pada sumbu Y. Sehingga dapat diambil kesimpulan bahwa tidak terjadi heterokedastisitas dalam model regresi.

Berdasarkan Tabel 4. dapat diketahui bahwa angka tolerance dari variabel bebas semuanya menunjukkan angka $>0,10$. Hal ini berarti bahwa tidak terjadi korelasi antar variabel bebas. Kemudian semua variabel bebas menunjukkan VIF $<10$. Dengan demikian disimpulkan bahwa model regresi tidak terjadi multikolinearitas antara variabel bebas tersebut.

\section{Uji Multikolinearitas}

Tabel 4. Hasil Uji Multikolinearitas

\begin{tabular}{|c|c|c|c|}
\hline Variabel Independen & Tolerance & VIF & Keterangan \\
\hline Umur $(\mathrm{X} 1)$ & 0,432 & 2,313 & Tidak Terjadi \\
\hline Tingkat Pendidikan (X2) & 0,870 & 1,149 & $\begin{array}{l}\text { Multikoliniearitas } \\
\text { Tidak Terjadi } \\
\text { Multikoliniearitas }\end{array}$ \\
\hline $\begin{array}{l}\text { Penghasilaan Suami/Anggota Keluarga Lainnya } \\
\text { (X3) }\end{array}$ & 0,728 & 1,373 & $\begin{array}{l}\text { Tidak Terjadi } \\
\text { Multikoliniearitas }\end{array}$ \\
\hline Jumlah Tanggungan Keluarga (X4) & 0,648 & 1,544 & $\begin{array}{c}\text { Tidak Terjadi } \\
\text { Multikoliniearitas }\end{array}$ \\
\hline Lama Pengalaman Bertani (X5) & 0,486 & 2,056 & $\begin{array}{c}\text { Tidak Terjadi } \\
\text { Multikoliniearitas }\end{array}$ \\
\hline
\end{tabular}

Sumber: Data primer diolah, 2019

\section{Uji Statistik}

Hasil estimasi factor penentu pendapatan wanita buruh tani padi sawah di Desa Wonosari dianalisis secara statistic dan diperoleh hasil yang disajikan dalam Tabel 5.

Dari hasil estimasi pada Tabel 5, dapat diketahui hasil persamaan regresi linier berganda dalam model penelitian ini adalah sebagai berikut: $Y=a+\beta_{1} X_{1}+\beta_{2} X_{2}+\beta_{3} X_{3}+\beta_{4} X_{4}+\beta_{5} X_{5}+e$

$Y=4508005,065-49003,549 X_{1}-41399,946 X_{2}+0,014 X_{3}+172957,673 X_{4}+$ $24868,080 \mathrm{X}_{5}$

\section{Koefisien determinasi $\left(R^{2}\right)$}

Dari hasil estimasi Tabel 5 dapat diketahui bahwa koefisien determinasi $\mathrm{R}^{2}$ sebesar 0,308 (30,8\%), yang menunjukkan bahwa variabel umur, tingkat pendidikan, pendapatan suami/anggota keluarga lainnya, jumlah tanggungan 
keluarga dan lama pengalaman berrtani dalam menjelaskan variasi nilai variabel pendapatan wanita buruh tani sebesar 30,8\%, sedangkan sisanya sebesar $69,2 \%$ dipengaruhi oleh variabel lain yang tidak dimasukkan dalam penelitian ini.

Tabel 5. Hasil Estimasi Faktor Penentu Pendapatan Wanita Buruh Tani Padi Sawah di Desa Wonosari

\begin{tabular}{|c|c|c|c|c|c|}
\hline \multirow{2}{*}{\multicolumn{2}{|c|}{ Uraian }} & \multicolumn{2}{|c|}{$\begin{array}{l}\text { Unstandardized } \\
\text { Coefficients } \\
\end{array}$} & \multirow[t]{2}{*}{$\mathrm{T}$} & \multirow[t]{2}{*}{ Sig. } \\
\hline & & B & Std. Error & & \\
\hline I (Constant) & & 4508005,065 & 778021,051 & 5,794 & 0,000 \\
\hline Umur (X1) & & $-49003,549$ & 14249,608 & $\begin{array}{r}- \\
3,439^{*}\end{array}$ & 0,001 \\
\hline Tingkat Pendidikan (X2) & & $-41399,946$ & 46811,519 & $-0,884$ & 0,380 \\
\hline $\begin{array}{l}\text { Penghasilaan Suami/ Anggota } \\
\text { Lainnya (X3) }\end{array}$ & Keluarga & 0,014 & 0,031 & 0,450 & 0,654 \\
\hline Jumlah Tanggungan Keluarga (X4) & & 172957,673 & 85793,689 & $2,016^{*}$ & 0,048 \\
\hline Lama Pengalaman Bertani (X5) & & 24868,080 & 11751,232 & $2,116^{*}$ & 0,038 \\
\hline R Square $\left(\mathrm{R}^{2}\right)$ & & & & & $\begin{array}{l}3 \\
8\end{array}$ \\
\hline$F_{\text {hitung }}$ & & & & & $\begin{array}{l}4 \\
7\end{array}$ \\
\hline $\mathrm{F}_{\text {tabel }}$ & & & & & $\begin{array}{l}3 \\
0\end{array}$ \\
\hline$t_{\text {tabel }}$ & & & & & $\begin{array}{l}0 \\
0\end{array}$ \\
\hline Signifikansi (a) 95\% & & & & & $\begin{array}{l}0 \\
5\end{array}$ \\
\hline
\end{tabular}

Sumber: Data primer diolah, 2019

Keterangan $(*)=$ Berpengaruh nyata pada taraf kepercayaan 95\%

\section{Uji Simultan (Uji F)}

Berdasarkan analisis data pada Tabel 5 Menunjukkan bahwa nilai Fhitung yang diperoleh adalah 5,437, sedangkan nilai F-tabel $(\mathrm{df1}=5$; df2 =61; $\mathrm{a}$ $=0,05$ ) diperoleh 2,370. Dengan demikian, nilai F-hitung > F-tabel atau 5,437 > 2,370 yang berarti nilai ini menyatakan pengaruh positif. Hal ini menunjukkan bahwa hipotesi penelitian di Desa Wonosari pada tingkat kepercayaan 95 persen yang menyatakan "variabel bebas (umur $\left(\mathrm{X}_{1}\right)$, tingkat pendidikan $\left(\mathrm{X}_{2}\right)$, pendapatan suami/anggota keluarga lainnya $\left(X_{3}\right)$, jumlah tanggungan keluarga $\left(\mathrm{X}_{4}\right)$, dan lama pengalaman bertani $\left(\mathrm{X}_{5}\right)$ ) berpengaruh secara simultan terhadap variabel terikat (pendapatan wanita buruh tani $(\mathrm{Y}))^{\prime \prime}$ terbukti kebenarannya dan diterima.

\section{Uji Parsial (Uji-t)}

Pengujian secara parsial digunakan untuk melihat pengaruh variabel umur, tingkat pendidikan, pendapatan suami/anggota keluarga lainnya, 
jumlah tanggungan keluarga dan lama pengalaman bertani terhadap pendapatan wanita buruh tani secara parsial. Hasil pengujiannya dapat dilihat pada nilai t-hitung Tabel 5. Untuk lebih jelasnya apakah variabel-variabel yang di uji berpengaruh signifikan atau tidak dapat dilihat pada uraian di berikut:

\section{$\operatorname{Umur}\left(X_{1}\right)$}

Berdasarkan hasil penelitian menunjukkan bahwa umur memiliki nilai thitung yaitu $-3,439$ yang berarti bahwa umur berpengaruh negatif dan signifikan terhadap pendapatan wanita buruh tani. Hal ini sesuai dengan apa yang terjadi di lingkungan Desa Wonosari, dimana hasil angket kuesioner yang telah disebar dan dianalisis secara deskripif menunjukkan bahwa secara keseluruhan wanita buruh tani berpendapat bahwa faktor umur menjadi pengaruh terhadap pendapatan wanita buruh tani, jika umur bertambah maka pendapatan juga akan cenderung semakin menurun mengingat tingkat produktivitas yang dihasilkan pekerja menurun karena badan akan mudah lelah bekerja. Hasil penelitian ini sejalan dengan yang diungkapkan Septia dkk (2017), bahwa umur berpengaruh negatif terhadap pendapatan tenaga kerja wanita, dimana umur tersebut adalah umur puncak bagi kemampuan seseorang. Sehingga, semakin bertambahnya usia seseorang maka fisik dan keterampilan akan mengalami penurunan yang kemudian berdampak kepada pendapatan.

\section{Tingkat Pendidikan $\left(\mathrm{X}_{2}\right)$}

Tingkat pendidikan formal/non formal disadari atau tidak dapat mempengaruhi keberhasilan seseorang untuk mendapat pekerjaan yang lebih baik, karena semakin tinggi pendidikan maka pengetahuan tentang pekerjaan yang mereka tekuni akan semakin banyak sehingga hasilnya akan semakin baik. Hasil penelitian yang dilakukan Putri (2013), mengungkapkan bahwa pendidikan berpengaruh positif dan signifikan secara parsial terhadap pendapatan rumah tangga miskin di Desa Bebandem Kabupatan Karangasem.

Namun, berdasarkan hasil penelitian yang dilakukan di Desa Wonosari, tingkat pendidikan tidak berpengaruh terhadap pendapatan wanita buruh tani. Ternyata nilai uji statistik -t-hitung yaitu -0,884 atau tidak signifikan. Penelitian ini didukung oleh penelitian yang dilakukan Amnesi (2012) bahwa tingkat pendidikan tidak ada berpengaruh terhadap pendapatan perempuan pada keluarga miskin di Kelurahan Kapal. Apabila terjadi penurunan tingkat penididikan maka akan terjadi penurunan pendapatan terhadap perempuan.

\section{Pendapatan Suami/Anggota Keluarga Lainnya $\left(X_{3}\right)$}

Berdasarkan hasil analisis statistik menunjukkan bahwa Pendapatan suami/anggota keluarga lainnya memiliki nilai t-hitung yaitu 0,450 yang berarti bahwa variabel pendapatan suami/anggota keluarga lainnya tidak 
berpengaruh terhadap pendapatan wanita buruh tani. Hal ini berarti bahwa tinggi rendahnya pendapatan suami dan anggota keluarga lain tidak mempengaruhi terhadap pendapatan buruh wanita tani. Namun apabila dilihat dari nilai koefisien regresi yang positif, ada kecenderungan bahwa pendapatan suami/anggota keluarga lainnya akan meningkatkan pendapatan buruh wanita tani.

\section{Jumlah Tanggungan Keluarga $\left(X_{4}\right)$}

Hasil penelitian pada Tabel 5 menunjukkan bahwa Jumlah tanggungan keluarga memiliki nilai t-hitung 2,016 yang berarti bahwa jumlah tanggungan keluarga berpengaruh positif dan signifikan terhadap pendapatan wanita buruh tani. Dengan demikian semakin banyak jumlah tanggungan keluarga wanita buruh tani maka akan semakin meningkatkan tingkat pendapatan wanita buruh tani tersebut, begitu pula sebaliknya. Sedikit banyak jumlah tanggungan akan mempengaruhi motivasi wanita buruh tani untuk bekerja. Jika mereka memiliki banyak jumlah tanggungan maka biaya pengeluaran untuk memenuhi kebutuhan sehari-hari akan bertambah, sehingga wanita tani harus bekerja lebih giat.

Hasil Penelitian Wijaya dan Wirathi (2013) sejalan dengan penelitian ini yang menyatakan bahwa jumlah tanggungan keluarga berpengaruh positif dan signifikan terhadap pendapatan ibu rumah tangga. Apabila jumlah tanggungan keluarga bertambah 1 orang maka akan mendorong ibu rumah tangga untuk bekerja lebih keras, dengan harapan kerja kerasnya akan menghasilkan pendapatan yang lebih besar.

\section{Lama Pengalaman Bertani $\left(X_{5}\right)$}

Berdasarkan hasil penelitian menunjukkan bahwa Lama pengalaman bertani memiliki nilai t-hitung yaitu 2,116 yang berarti bahwa lama pengalaman bertani berpengaruh positif dan signifikan terhadap pendapatan wanita buruh tani. Selanjutnya koefisien regresi 24.868,080, menunjukkan bahwa apabila variabel lama pengalaman berrtani meningkat sebesar 1 tahun, maka pendapatan wanita buruh tani akan cenderung meningkat sebesar $24.868,080$ rupiah. Hasil penelitian ini sejalan dengan yang diungkapkan Sholeha dkk (2016), bahwa secara parsial variabel lama usaha berpengaruh positif dan signifikan terhadap pendapatan pekerja wanita pedagang online.

Berdasarkan uraian di atas dapat disimpulkan bahwa dari kelima variabel bebas, ternyata variabel umur, jumlah tanggungan keluarga dan lama pengalaman bertani merupakan variabel yang paling dominan (berpengaruh nyata dan signifikan) terhadap pendapatan wanita buruh tani. Hal ini terbukti dari angka koefisien pendapatan sebesar 4.508.005,065, angga t-hitung yang paling besar yakni $-3,439$ dan angka probalilitas terkecil yaiki 0,001. Untuk variabel tingkat pendidikan dan pendapatan suami/anggota keluarga lainnya merupakan variabel yang tidak dominan (tidak berpengaruh nyata dan tidak 
signifikan) terhadap pendapatan wanita buruh tani, sehingga hipotesis penelitian terjawab.

\section{Kontribusi Pendapatan Wanita Buruh Tani Terhadap Pendapatan Keluarga}

Kontribusi pendapatan wanita buruh tani adalah besarnya sumbangan pendapatan wanita terhadap total pendapatan keluarga yang dihitung dalam persen (\%). Pendapatan wanita buruh tani berasal dari upah yang didapat ketika bekerja sebagai buruh di setiap kegiatan usahatani padi sawah ditempat orang lain (buruh tani) sehingga dapat menambah pendapatan keluarga.

Pendapatan keluarga adalah jumlah penghasilan yang diterima keluarga untuk jangka waktu satu musim tanam yang diperoleh dari para anggota keluarga (suami, istri, dan anak) terdiri dari pendapatan usahatani dan non usahatani tanpa dikurangi biaya. Untuk melihat sumber-sumber pendapatan keluarga, dapat dilihat pada Tabel 6.

Berdasarkan hasil penelitian dapat diketahui bahwa kontribusi pendapatan wanita buruh tani padi sawah terhadap pendapatan keluarga di Desa Wonosari adalah sebesar 15,7 persen artinya kontribusi pendapatan wanita buruh tani tergolong sangat rendah yaitu antara 1-20 persen. Hal ini selaras dengan penelitian yang dilakukan Bhasroni dan Yuliati (2015), menunjukkan bahwa kontribusi wanita buruh tani terhadap pendapatan keluarga masih rendah yaitu sebesar 17 persen. Pada aspek aktivitas keterlibatan wanita lebih dominan dibandingkan dengan pria. Jenis aktivitas yang dominan dilakukan oleh wanita adalah pada kegiatan persemaian, pen anaman, penyulaman, penyiangan, pengendalian hama penyakit dan pemanenan, sedangkan aktivitas yang dilakukan oleh pria adalah pada kegiatan pengolahan lahan, penyiraman dan pemupukan.

Berdasarkan hasil penelitian dapat diketahui bahwa kontribusi pendapatan wanita buruh tani padi sawah terhadap pendapatan keluarga di Desa Wonosari adalah sebesar 15,7 persen artinya kontribusi pendapatan wanita buruh tani tergolong sangat rendah yaitu antara 1-20 persen. Hal ini selaras dengan penelitian yang dilakukan Bhasroni dan Yuliati (2015), menunjukkan bahwa kontribusi wanita buruh tani terhadap pendapatan keluarga masih rendah yaitu sebesar 17 persen. Pada aspek aktivitas keterlibatan wanita lebih dominan dibandingkan dengan pria. Jenis aktivitas yang dominan dilakukan oleh wanita adalah pada kegiatan persemaian, pen anaman, penyulaman, penyiangan, pengendalian hama penyakit dan pemanenan, sedangkan aktivitas yang dilakukan oleh pria adalah pada kegiatan pengolahan lahan, penyiraman dan pemupukan. 
Tabel 6. Rata-rata Sumber Pendapatan Keluarga Wanita Buruh Tani

\begin{tabular}{|c|c|c|c|}
\hline No & Uraian & Rata-rata Total Pendapatan Keluarga (Rp/MT) & $\begin{array}{c}\text { Persentase } \\
(\%)\end{array}$ \\
\hline \multirow[t]{7}{*}{1} & Usahatani & 8.307 .640 & \\
\hline & - $\quad$ Tanaman Pangan & 4.565 .299 & 23,3 \\
\hline & - $\quad$ Sayur-mayur & 35.224 & 0,2 \\
\hline & - Buah-buahan & 62.521 & 0,3 \\
\hline & - $\quad$ Peternakan & 2.121 .343 & 20,8 \\
\hline & - $\quad$ Perkebunan & 1.476 .985 & 7,5 \\
\hline & - $\quad$ Perikanan & 46.269 & 0,2 \\
\hline \multirow[t]{7}{*}{2} & Non Usahatani & 11.314 .776 & \\
\hline & - $\quad$ Dagang & 380.896 & 1,9 \\
\hline & - Toko & 101.493 & 0,5 \\
\hline & - $\quad$ Bengkel & 370,149 & 1,9 \\
\hline & - Swasta & 7.391 .045 & 37,7 \\
\hline & - $\quad$ Buruh wanita tani & 3.071 .194 & 15,7 \\
\hline & Total & 19.622 .418 & 100 \\
\hline
\end{tabular}

Sumber: Data primer diolah, 2019

Berdasarkan hasil penelitian dapat disimpulkan bahwa kontribusi wanita buruh tani terhadap pendapatan keluarga masih sangat rendah karena kurang dari 20 persen. Namun kontribusi pendapatan wanita dianggap sangat membantu perekonomian keluarga dan keterlibatan wanita tani dalam kegiatan usahatani padi sawah sebagai buruh tidak dapat diabaikan. Sebab ada beberapa kegiatan usaha tani yang banyak menggunakan tenaga kerja wanita buruh tani seperti pada tahap kegiatan pencabutan bibit, penanaman, penyiangan dan pemanenan.

\section{SIMPULAN DAN SARAN}

\section{Simpulan}

Berdasarkan uraian yang telah diungkapkan pada pembahasan, maka dapat diambil beberapa kesimpulan sebagai berikut: 1)Rata-rata curahan waktu kerja wanita buruh tani padi sawah di Desa Wonosari yang dicurahkan adalah sebesar $445 \mathrm{Jam} / \mathrm{MT}$; 2) Pendapatan wanita buruh tani padi sawah di Desa Wonosari Kecamatan Megang Sakti adalah sebesar Rp 3.071.194.-/MT; 3) Faktor penentu pendapatan wanita buruh tani padi sawah di Desa Wonosari dari kelima variabel bebas, ternyata ada tiga variabel yang berpengaruh nyata dan signifikan terhadap pendapatan wanita buruh tani yaitu umur, jumlah tanggungan keluarga dan lama pengalaman bertani; 4) Rata-rata kontribusi pendapatan wanita buruh tani padi sawah terhadap pendapatan keluarga di Desa Wonosari sebesar 15,7 \%. Hal ini berarti bahwa kontribusi wanita buruh tani masih tergolong dalam kategori sangat rendah yaitu antara $1 \%-20 \%$.

124 | Ella Anggraini; Basuki Sigit Priyono; Sriyoto; Faktor Penentu Penda... 


\section{Saran}

1) Kepada Pemerintah agar kiranya dapat memberikan bantuan modal kepada wanita buruh tani untuk dapat dipergunakan dalam melakukan suatu usaha sampingan; 2) Kepada wanita buruh tani perlu mengembangkan jati dirinya sehingga tidak hanya terkenal sebagai tenaga kerja domestik namun dapat berperan dalam kegiatan produktif, khususnya dalam membantu ekonomi rumah tangga dan pertanian perlu diberdayakan kaum wanita; 3)Kepada peneliti selanjutnya agar kiranya melakukan penelitian mengenai faktor penentu sosial apa saja yang mempengaruhi pendapatan wanita buruh tani padi sawah terhadap pendapatan keluarga.

\section{DAFTAR PUSTAKA}

Andryan Setyadharma. (2010). Uji Asumsi Klasik Dengan SPSS.Semarang: FE UNES.

Amnesi, Dance. 2012. Analisis Faktor-Faktor Yang Berpengaruh Terhadap Pendapatan Perempuan Pada Keluarga Miskin Di Kelurahan Kapal Kecamatan Mengwi Kabupaten Badung. Diunduh dari https://media.neliti.com/media/publications/44678-ID-analisisfaktor-faktor-yang-berpengaruh-terhadap-pendapatan-perempuanpada-kelua.pdf. Pada tanggal 26 Mei 2019 jam 10.30 WIB.

Bhastoni, K., dan Yuliati, Y. Peran Wanita Tani di Atas Usia Produktif Dalam Usahatani Sayuran Organik Terhadap Pendapatan Rumah Tangga di

Desa Sumberejo Kecamatan Batu. Habitat. 26 (2): 119-129.

Djarwanto, Ps. 2001. Mengenal Beberapa Uji Statistik Dalam Penelitian: Edisi Kedua. Dosen Fakultas Ekonomi Universitas Sebelas Maret. Liberty Yogyakarta. Surakarta.

Muttaqin, E.Z., Rosnita, dan Yusmini. 2015. Curahan Waktu Kerja Dan Pengambilan Keputusan Wanita Keluarga Petani Kelapa Sawit Pola Plasma Di Desa Sari Galuh Kecamatan Tapung Kabupaten Kampar. Jom Faperta. 2 (1).

Nurmanaf, A. Rozany. 2006. Peranan Sektor Luar Pertanian terhadap Kesempatan dan Pendapatandi Pedesaan Berbasis Lahan Kering. Jurnal SOCA. 8. (3): 318-322.

Prasetyo, S.A., Romdhon, M.M., dan Badrudin, R. 2016. Kontribusi Pendapatan Usahatani Padi Sawah, Itik Petelur Dan Ikan Air Tawar Terhadap Pendapatan Total Usahatani di Kabupaten Lebong. Jurnal AGRISEP. 15 (1): 83-90.

Putri, A.D., dan Setiawan, N.D. 2013. Pengaruh Umur, Pendidikan, Pekerjaan Terhadap Pendapatan Rumah Tanga Miskin Di Desa Bebandem. EJurnal Ekonomi Pembangunan Universitas Udayana. 2 (4): 173-180. 
Sabainingrum. 1998. Curahan Tenaga Kerja Dan Pendapatan Masyarakat Pada Objek Wisata Agri Salak Pondoh Desa Bangun Kerja. Fakultas Pertanian, Institut Pertanian Bogor. Bogor.

Septia, M.A., Br, Arfida, dan Kusuma, H. 2017. Peran Tenaga Kerja Wanita Home Industri Batik dan Kontribusinya Terhadap Pendapatan Keluarga di Desa Mojosari Kecamatan Kauman Kabupaten Tulungagung. Jurnal Ilmu Ekonomi. Vol 1 Hal. 527-537.

Shinta, A. 2011. Ilmu Usahatani. UB Press. Malang Yuwono, Dian M. 2013. Pengaruh keutamaan Gender Dalam Pembangunan Pertanian: Kasus Pada Pelaksanaan Program Feati Di Kabupaten Magelang. Badan Pengkajian Teknologi Pertanian. Jawa Tengah. SEPA.10 (1): 140 - 147.

Sholeha, M., Istiyani, N., dan Luthfi, A. 2016. Faktor Yang Mempengaruhi Pendapatan Pekerja Wanita Pedagang Online di Kabupaten Banyuwangi. Artikel Ilmiah Mahasiswa. Fakultas Ekonomi dan Bisnis, Universitas Jember (UNEJ).

Sumantri, B. dan Budi Ansori. 2004. Kontribusi Pendapatan Ibu Rumah Tangga Terhadap Pendapatan Keluarga. Jurnal Agrisep. 2 (2) :103-111.

Wijaya, I.M.A., Wirathi, I.G.A.P. 2013. Faktor-Faktor Yang Mempengaruhi Pendapatan Ibu Rumah Tangga Yang Bekerja Pada Sektor Informal Di Kelurahan Dauh Puri Kauh, Denpasar Barat. E-Jurnal EP Unud. 2 (5): 269-276.

Yunilas. 2005. Faktor-Faktor Yang Mempengaruhi Curahan Waktu Tenaga Kerja Wanita Dalam Memelihara Ternak Sapi Di Kecamatan Hamparan Perak. Jurnal Agribisnis Peternakan. 1 (3): 117-122.

Yusmaniar, Rosnita, dan Edwina, S. 2015. Curahan Waktu Kerja Dan Pengambilan Keputusan Wanita Dalam Keluarga Petani Kelapa Sawit Pola Swadaya Di Desa Pantai Cermin Kecamatan Tapung Kabupaten Kampar. Jom Faperta. 2 (1).

Yuwono, Dian M. 2013. Pengaruh keutamaan Gender Dalam Pembangunan Pertanian: Kasus Pada Pelaksanaan Program Feati Di Kabupaten Magelang. Badan Pengkajian Teknologi Pertanian. Jawa Tengah. SEPA.10 (1): 140 - 147.

126 | Ella Anggraini; Basuki Sigit Priyono; Sriyoto; Faktor Penentu Penda... 